\title{
55-Kur’ân'da geçen lider kavramları ve özellikleri
}

\section{Kemal ŞìMŞEK ${ }^{1}$}

APA: Şimşek, K. (2022). Kur'ân'da geçen lider kavramları ve özellikleri. RumeliDE Dil ve Edebiyat Araştırmaları Dergisi, (26), 911-929. DOI: 10.29000/rumelide.1074124.

\section{$\ddot{O} \mathbf{z}$}

Kur’ân, Müslümanların söz ve davranışlarında uymaları gereken kuralların yazılı olduğu kitaptır. Allah, Kur'ân'da insanlara üstlenmeleri gereken bir takım sorumlulukları bildirmiştir. Bu sorumluluklardan biri “emânet”i üstlenme sorumluluğudur. Çünkü Kur’ân'da Allah’in göklere, dağlara ve yerlere "emânet”i üstlenmelerini teklif ettiği onların bu sorumluluğu almaktan kaçındıkları ancak insanoğlunun bu sorumluluğu üstlendiği bildirilmektedir. Müslüman düşünürlerin çoğu insanın üstlendiği “emânet”i yönetme, idare etme şeklinde anlamışlardır. Eskiden beri emâneti üzerine alacak olan insanların kimler olduğu konusu merak edilen bir konu olmuştur. Dolayısıyla Kur'ân'da emâneti üstlenip yönetme sorumluluğunu alan insanların hangi adlarla isimlendirildiği, birinin yönetimine neden ihtiyaç duyulduğu konuları sürekli sorgulanmıştır. İnsan sosyal bir varlıktır. İnsanın sahip olduğu bu özellik, insanları bir arada yaşamaya mecbur etmiştir. Bir arada yaşamak da belli ortak kurallarla mümkün olmaktadır. Dolayısıyla bu kuralları uygulayacak, kontrol edecek, kimselere her zaman ihtiyaç duyulmaktadır. Var olan kuralları uygulayacak olan kimseler, farklı yer, zaman ve toplumlarda başkan, önder, lider anlamına gelen değişik adlarla isimlendirilmişlerdir. Ancak yönetici olan kimselere verilen isimlerin hepsi liderlik etme, yönlendirme, yönetme anlamlarını ifade etmektedir. Kur'ân'da insanları yöneten, lider veya liderler sahip oldukları özellikler, yetkilerinin kaynağı ve yönettikleri topluluk bakımından farklı isimlerle ifade edilmişlerdir. Ayrıca liderlere ait özellikler, liderlerin fikir, karar ve davranışlarının sonuçları örneklerle anlatılmış ve muhataplara buna göre davranmaları için öğütler verilmiştir. Kuran'da liderler, tek başına lider ve sosyal sınıf olarak liderler topluluğu olmak üzere iki kısma ayrılmaktadır. Bu araştırmada Kur'ân'da geçen lider ve liderlikle ilgili kavramlar incelenecek, lider ve liderlerin özellikleri, kaç tür lider bulunduğu ortaya konmaya çalışılacaktır.

Anahtar kelimeler: Kur’ân, lider, liderlerin özellikleri

\section{Leader concepts in Qur'an and their characteristics}

\begin{abstract}
Qur'an is the book in which the rules that Muslims should obey in their words and behaviours have been specified. God has conveyed a series of responsibilities in Qur'an that should be obeyed by all people. One of these responsibilities is the responsibility of taking on the "trust". Because it is indicated in the Qur'an that God has offered the skies, mountains and lands to take on the "trust" but that they refrained from doing so but that humankind has taken on this responsibility. Majority of the Muslim thinkers have interpreted the "trust" taken on by humankind as management and guidance. It has long been a matter of interest as to who the people are to take on the trust. Therefore, it has always been questioned which names the people have in the Qur'an who have taken on the trust
\end{abstract}

Öğr. Gör., Akdeniz Üniversitesi, İlahiyat Fakültesi, Sosyal Bilimler Enstitüsü, Arap Dili ve Belagati ABD (Antalya, Türkiye), simsek108o@gmail.com, ORCID ID: oooo-0oo1-9321-9383 [Araştırma makalesi, Makale kayıt tarihi: 07.01.2022-kabul tarihi: 20.02.2022; DOI: 10.29000/rumelide.1074124]

Adres Address

RumeliDE Dil ve Edebiyat Araşttrmaları Dergisi Osmanağa Mahallesi, Mürver Çiçeği Sokak, No:14/8 Kadıköy - İSTANBUL / TÜRKIYE 34714 e-posta: editor@rumelidec

RumeliDE Journal of Language and Literature Studies Osmanağa Mahallesi, Mürver Çiçeği Sokak, No:14/8 Kadıköy - ISTANBUL / TURKEY 34714

e-mail: editor@rumelide.com, tel: +90 5057958124, +902167730616 phone: +90 505 7958124, +90 2167730616 
and why is there a need for the administration of one person. Humans are social beings. This quality of humans has forced them to remain together. Living together is possible only through certain mutual rules. Hence, it is always necessary to have people who will impose these rules and control them. People who put into effect the already existing rules in societies have taken on different names throughout history which all mean leader, apostle, and chief. However, all the names given to these individuals express meanings of leading, guiding and directing. The characteristics in the Qur'an of leader or leaders who guide people have been expressed in different names based on the source of their authority and the community they are guiding. In addition, characteristics of leaders along with the outcomes of the decisions and behaviours of leaders have been explained with examples and advices have been provided for all related individuals. Leaders in Qur'an are classified into two groups as leaders by themselves and leaders as a social class. The aim of the present study was to examine the concepts in Qur'an related with leaders and to put forth the types of leaders.

Keywords: Qur'an, leader, characteristics of leaders

\section{Giriş}

Lider kavramı İngilizce "leader” kelimesinden Türkçeye geçmiş bir kavramdır. Türkçesi “önder”, "başkan” olan lider kavramı; bulunduğu çevreye yarar sağlayan, süregelen gelenekte köklü değişiklikler yapan ve çevreyi yönetmek için sezgi, zekâ ve bilgiye dayalı karar veren kişi anlamına gelmektedir. Lider, aynı zamanda elindeki gücü kullanabilme kapasitesine bağlı olarak, çevresini etkileyen, gerektiğinde aldığı zor kararların ve sonuçlarının ardında durmasını bilen kimse anlamına da gelmektedir. Lider, , başkalarından bilgi alarak bilgilenen, çevresine danışan ancak son kararı tüm sorumluluğu alarak hep kendisi veren, çevresinde bulunan bireyleri hitabet gücü, sahip olduğu bilgi ve feraseti ile etkileyip, sürükleyen bir yapıya sahip kimsedir.

Liderlerin, meşruiyet kaynakları birbirinden farklıdır. Toplumsal normların yüklediği rolü üstlenmek, inandığı değerleri savunmak, bir soya bağlı olmak, maddî-manevî gücü elinde bulundurmak veya ilahi irade tarafından seçilmek gibi pek çok etken liderlerin meşruiyetinin kaynaklarındandır. Liderler, sahip oldukları özellikler, liderliklerinin meşruiyet kaynağı, liderlik teorileri gibi bir takım sebepler yüzünden birbirlerinden farklı isimlerle ifade edilmişlerdir. Kur'ân'da liderlikle ilgili olarak geçen kelime ve kavramları, münferit anlam ifade eden liderler ve topluluk halinde liderlik anlamı ifade eden liderler şeklinde ikiye ayırmak mümkündür.

Allah Kur’ân-ı Kerîm'de, “Doğrusu Biz, sorumluluğu "emâneti” göklere, yere, dağlara sunmuşuzdur da onlar bunu üstlenmekten çekinmişler ve ondan korkup titremişlerdir; ancak emâneti insan üstlendi...)”( Kur'ân, Ahzab, 33/72) şeklinde buyurmuştur. Göklerin, yerin ve dağların kaçınıp, insanın üstlendiği "emânet" nedir ve Allah, insanın bu emâneti yüklenmesine neden izin vermiştir? Şeklindeki sorular liderlik kavramıyla yakından ilişkilidir. Bu yüzden önce emânet kavramı sonra da emâneti üstlenen insanlarla yani liderlerle ilgili kavramlara yer verilecektir.

\section{Emânet}

Emânet (أمانة) kelimesi, Arapça'da (E-M-N أمن) kökünden türemiş bir mastardır. Sözlükte, güvenmek, korku ve endişeden güvende olmak manasının yanı sıra güvenilir bir kimseye korunması için bırakılan şey manasına da gelmektedir ki bu kullanımı daha yaygındır (el-İsfehânî, 1992:140). Terim olarak; bir

\footnotetext{
Adres $\mid$ Address

RumeliDE Dil ve Edebiyat Araşttrmaları Dergisi Osmanağa Mahallesi, Mürver Çiçeği Sokak, No:14/8 Kadıköy - İSTANBUL / TÜRKIYE 34714 e-posta: editor@rumelide.com

RumeliDE Journal of Language and Literature Studies Osmanağa Mahallesi, Mürver Çiçeği Sokak, No:14/8 Kadıköy - ISTANBUL / TURKEY 34714

e-mail: editor@rumelide.com, tel: +90 5057958124, +90 2167730616 phone: +90 505 7958124, +90 2167730616
} 
eşya veya değeri gönül huzuru içinde ve güvenle başka birine teslim etmek veya aynı şartlarla teslim almak anlamına gelmektedir (Akyüz, 1997:15).

Emânet kelimesinin Kur’ân-ı Kerîm'de iki farklı manada kullanıldı̆̆ı görülmektedir. Bu iki manadan birincisine göre emânet; güvenilir birine tevdi edilen mal veya eşya demektir. Bu manadaki kullanımına Kur'ân'da geçen şu ayet örnek olarak verilebilir: "Yine onlar (o müminler) ki, emânetlerine ve ahitlerine riâyet ederler.”(Kur'ân,23/o8;70/32) Emânet kavramının ikinci manası ise; "görev bilinci, sorumluluk, iradesini kullanma yeteneği” anlamındadır (Akyüz, 1997: 16). Ahzab Suresi'nin: "Doğrusu Biz, sorumluluğu (emâneti) göklere, yere, dağlara sunmuşuzdur da onlar bunu yüklenmekten çekinmişler ve ondan korkup titremişlerdir; onu insan yüklendi. Doğrusu o çok zâlim ve çok câhil. (kabulüne rağmen emânete hiyanet etmektedir)" (Kur'ân, 32/72) ayeti bu kullanımına örnek olarak vermek mümkündür.

"Emânet" kavramı için âlimler tarafindan farklı yorumlar getirildiği de görülmektedir. Âlimlerin bazıları "emânet"; ibadetler, bütün teklifler, Allah'ın insanlardan aldığı misaktır demişlerdir. Zemahşerî "emânet" kavramının teklif anlamına geldiğini savunmaktadır. O’na göre birini yükümlü kılmak, kendi tabiatına uygun davranmasını istemek demektir. Ayette geçen göklerin, dağların, yerin kabul etmediği emânet budur. Zira insan dışındaki varlıklar ne amaçla yaratıldılarsa o şekilde hareket etmek durumundadırlar kendi doğalarına aykırı davranamazlar. Öyle ki meleklerin ibadetleri bile bir yükümlülük sonucu değil insandaki yeme içme gibi kendi doğalarının bir gereğidir (Zemahşerî, 276277). İbn Teymiyye es-Siyasetu'ş-Şer'iyye adlı kitabında emâneti Allah tarafından insana verilen yeryüzünü idare etme görevi olarak tefsir etmektedir. İbn Teymiyye bu görüşünü "umerâ ayeti” olarak da bilinen "Hiç şüphesiz Allah size, emânetleri ehline teslim etmenizi ve insanlar arasinda hükmettiğiniz zaman adaletle hükmetmenizi emreder. Allah size ne güzel öğüt veriyor. Şüphesiz Allah işitir ve görür" (Kur'ân,4/58) ayete dayandırmaktadır (İbn Teymiyye, 1999: 29).

Hadis-i şeriflerde "emânet” kavramının Kur'ân'da bahsedilen manalarının yanı sıra "yöneticilik, yapılan vaatler, özel meclislerde konuşulan sözler, verilen sırlar, evlenilen kadınların emânet olarak görülmesi” gibi anlamları da içerdiği aşağıdaki hadislerden anlaşılmaktadır.

Emânet kavramının "yöneticilik" manasında olduğunu gösteren hadislerden biri meâlen şu şekilde zikredilmektedir: Ebi Zer el-Ğifarî dedi ki: “ Rasulullah (s.a.v.)'e bana memurluk veriniz dedim. Allah'ın elçisi (s.a.v.), elini omzuma vurarak: Ey Eba Zer, sen zayıfsın ve bu iş bir emânettir. Emânet, kıyamet günü gereği gibi yerine getirmeyen için perişanlk, pişmanlk doğurur" dedi (Müslim, İmâre, 16).

Bir diğer hadis-i şerifte ise "emânet”, "yöneticilerin üstlendiği sorumluluk" anlamında kullanılmıştır. Rasûlullah (s.a.v.) şöyle buyurmuştur: "Emânet kaybedilince kıyameti bekleyin. Emânet nasıl kaybolur? diye sordular. İşler ehil olmayanlara teslim edilince" diye cevapladı" (Buharî, Rikak, 35; İlm, 2).

Kur'ân, hadis ve sözlükteki anlamlarına bakıldığında emânet kavramının; koruması için birine bırakılan mal, birinin diğeri üzerindeki hakları ve yerine getirmek için birinin üstlendiği görev, sorumluluk, teklif manalarına geldiği anlaşılmaktadır.

Kur'ân-1 Kerîm'de emâneti üstlenen kimselerle ilgili münferit anlamda liderlik ifade eden birçok kavram yer almaktadır. Bunların başında "halîfe" kavramı gelmektedir.

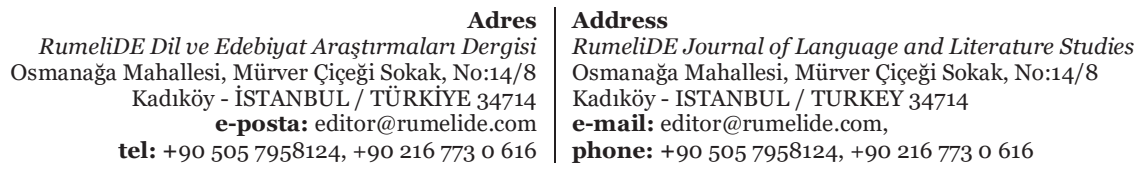


914 / RumeliDE Journal of Language and Literature Studies 2022.26 (February)

Leader concepts in Qur'an and their characteristics / K. Şimşek (pp. 911-929)

\section{Kur’ân ve sünnette geçen lider ve liderlikle ilgili kavramlar}

\subsection{Halîfe}

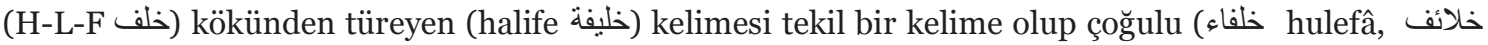
halâif, خو الف hevâlif) şeklindedir. Sözlükte; "birinin peşi sıra gitmek, ardından gelmek, yerine geçmek, yerini doldurmak, devlet başkanı, hükümdar" anlamlarına gelir (el-İsfehânî, 2012: 207). Terim olarak; "bir kimsenin yerine geçen, onun ardından yöneticiliğe gelen kimse" demek olup, İslâm geleneğinde; "devlet başkanı, tarikatlarda önceki tarikat liderinin yerini alan yeni postnişin" için kullanılan bir isimdir (el-İsfehânî, 2011: 293-295).

Halîfe kavramı, Kur'ân'da "sonradan gelen" anlamında tekil olarak ( خليفة halîfe) şeklinde iki yerde (Kur’ân, 2/30; 38/26); "geriye kalan" anlamında çoğul olarak ( خو الف havâlif) şeklinde iki yerde (Kur'ân, 9/87-93) ; (خلائف halâif) "hükümdar" manasında çoğul şekilde dört yerde (Kur'ân, 6/165; 10/14; 35/39); (خلفاء hulefâ) "yerine geçmek, yerini almak” manasında çoğul şekilde üç yerde (Kur’ân, 7/69-74; 27/62) geçmektedir.

Halîfe kelimesinin, tekil olarak geçtiği yerlerden biri Bakara Suresi'ndeki şu ayettir: "Rabbin meleklere, ben yeryüzünde bir Halîfe yaratacağım dedi...”(Kur'ân,2/30) Ebu's-Suud bu ayette geçen "halife" kavramı ile Hz. Âdem'in kastedildiğini söylemiştir (el-Amadî, 2021:299). Zaten eski âlimler bu ayetten hareketle yeryüzünde ilk halîfenin Hz. Âdem olduğu hükmüne varmış; yeryüzünün idaresi görevinin Allah tarafından bu şekilde insanoğluna verildiğini vurgulamışlardır. Halîfe, kavramının Kur'ân'da tekil olarak geçtiği bir diğer yerde ise muhatap Hz. Davud (a.s)'dır. Orada da Allah, Hz. Davud (a.s)'in Halîfe yapılmasının sebebini, insanlar arasında adaletle hükmetmesi şartına bağlamıştır (Kur'ân, 38/26). Kavramın çoğul olarak geçtiği ayetlere bakıldığında ise خو الف havâlif çoğul lafzıyla "savaşa gitmeyip geride kalanlar (Kur'ân, 9/87-93) yeryüzüne hâkim kimseler, iktidara gelen sorumlu kimseler, yönetici, erk sahibi (Kur'ân, 6/165; 10/14,73; 35/39) anlamlarında kullanıldığı anlaşılmaktadır.

Seyyid Kutub, fi Zilâli'l-Kur'ân adlı tefsirinde "halîfe" kavramını şöyle izah etmektedir: "Allah, Hz. Adem (a.s) ile bir takım ahitler yapıp, şartlar koşmak suretiyle yeryüzünün anahtarını (yönetimi görevini) ona teslim etmiştir. Hz. Adem (as)'a kendisini yeryüzünde temsil edip, hilafet görevini yürütebilmesi için bir takım bilgiler öğretmiştir (Kutub, 2012; I, 113).

Kur'ân'ın adeta açıklayıcı konumunda olan ve Kur'ân'dan sonra ikinci kaynak olarak kabul edilen hadisi şeriflerde de Halîfe kelimesi geçmektedir. Hadis-i şeriflerde de "halîfe" kavramı Kur'ân'daki manalarının aynıyla (birinin ardından gelen, önceki yöneticiden sonra gelen, giden bir liderin yerine geçen, yönetici, iktidar sahibi) anlamlarında kullanılmıştır. Kavramın hadislerdeki kullanımlarına aşă̆ıdaki hadisleri örnek verilebilir.

Hz. Muhammed (s.a.v.), :"Her nebinin ardından başka bir nebi gelmiştir. Ancak benden sonra nebi gelmeyecek, halîfeler (hulefâ) gelecek, onlarm da sayıları çok olacaktır...” (Buharî, Ehadisu'l-enbiya, 50) Bir başka rivayette: "Benden sonra halifeler olacak bildiklerini yapacaklar, emr olunduklarıyla amel edecekler, ancak onlardan sonra gelen halifeler, bilmedikleriyle ve emr olunmadıklarıyla amel edecekler..."(Ahmed el-Bustî 15/41), bir diğer hadiste ise: "Nebilerden sonra Allah'in kitabina göre amel eden kullarna adaletli davranan haliffeler gelecek. Haliffelerden sonra intikam alan ve erkekleri öldüren melikler (mülûk) gelecek" (el-Beyhakî, 7/133) diye buyurmuştur. Zikredilen hadislerden de

\footnotetext{
Adres

RumeliDE Dil ve Edebiyat Araşttrmaları Dergisi Osmanağa Mahallesi, Mürver Çiçeği Sokak, No:14/8 Kadıköy - İSTANBUL / TÜRKIYE 34714 e-posta: editor@rumelide.com

RumeliDE Journal of Language and Literature Studies

Osmanağa Mahallesi, Mürver Çiçeği Sokak, No:14/8

Kadıköy - ISTANBUL / TURKEY 34714

phone: +90 5057958124, +902167730616
} 
anlaşılacağı üzere hadis-i şeriflerde "halîfe" kavramı genel olarak "devlet başkanı, yönetici, iktidara gelen kimseler” anlamlarında kullanılmıştır.

Kavramın sözlüklerde, Kur’ân'an ve hadislerde "ard, sırt, ardından gelen, sonradan gelen, yerine geçen, önceki birinin yerine tayin olunan" manalarında kullanılmış olduğu; terim olarak ise daha çok bir topluluk, kavim ve bir devleti yöneten, devletin başında bulunan, sorumlu olduğu kimseleri yöneten kimse anlamında kullanıldığı görülmektedir.

Kavramın açıklamalarından da kısaca şunu anlamak mümkündür. Allah, yeryüzüne bulunan diğer varlıkları yönetme, onlara hükmetme yetkisini insanoğluna vermiştir. Yani insana, yeryüzünde bir nevi kendisini temsil etme görevini vermiş ancak bunu da adaletli, bilgili, ilahi kurallarla amel etmesi kaydı şartına bağlamıştır. Öyleyse insanın, Allah’ın halîfesi olabilmesi, şarta bağlıdır. Çünkü yüce yaratıcı adına iş görebilecek ve O'nu yeryüzünde temsil edecek olan insanın haliffelik özelliklerine haiz olması ve o makamın gerektirdiği sorumlulukları üstlenmesi gerekir ki ilahi iradenin yeryüzünde gerçekleşmesini sağlayabilsin. O halde Allah'ın belirlediği şartlara haiz olan her insanda da bu yetkiyi kullanabilme potansiyeli ve hakkı mevcuttur demek mümkün olmalıdır.

\section{2. İmam}

Tekil lider anlamı ifade eden kavramlardan biri de "imam” kavramıdır. (E-M-M أمَّ) kökünden türeyen (إمام kelimesinin çoğulu (eimme (إئمة şeklinde gelmektedir. Sözlükte; "önde olmak, başı çekmek, imam olmak (el-Mutarrizî, 1982:45) önder, lider, âlim, öncü, rehber” (İbn Manzur, I, 102) manalarına gelmektedir. Terim olarak; "devlet başkanı, cemaate namaz kıldıran, bir mezhebin başında bulunan kimse” (Küçükaşçı, 2004/179) anlamlarına gelmektedir.

İmam kavramı, Kur'ân'da altı yerde "imam إمام" (Kur'ân, 2/24; 15/79; 25/74; 36/12; 46/12) şeklinde tekil, beş yerde de "eimme أئمة şeklinde çoğul olarak geçmektedir. Tekil olarak geçtiği yerlerden birincisinde "açık yol" (Kur'ân, 15/79), ikincisinde "levh-i mahfuz" (Yasin, 36/12), diğer ayetlerde ise; önder (iyi önder için Kur’ân, 2/124; kötü önder için, Kur’ân, 9/12), lider, rehber, yol gösterici manalarına geldiği zikredilen ayetlerden anlaşılmaktadır. "İmam" kelimesi, tekil olarak geçtiği yerde Hz. İbrahim (a.s) hakkında kullanılmıştır. Orada Allah şöyle buyurmaktadır: "Bir zamanlar Rabbi İbrahim (a.s)’i bir takım kelimelerle sinamış, onları tam olarak yerine getirince: Ben seni insanlara imam/önder yapacağım demişti...” ( Kur’ân, 2/124).

Dikkat edilirse tıpkı Halîfe kavramında olduğu gibi burada da önderlik/yöneticilik "bir takım bilgilere sahip olma ve sınava tabi tutulma" şartına bağlanmıştır. Buradan hareketle yöneticilik görevine getirilecek kişilerin belli bilgilere sahip olmaları ve sınanmaları gerektiği sonucu çıkarılabilir.

Hadis-i şeriflerde "imam" çoğulu "eimme" kavramı, Kur'ân'da geçen manalarının aynı ile (cemaate namaz kıldıran, devlet başkanı) anlamında kullanılmıştır. Hz. Muhammed (s.a.v.), "Devlet başkanı, (millet için) bir kalkandır. Onun ardında onun emrinde harp yapılır. Onunla (düşmanlardan) korunulur. Eğer imam millete Allah'tan korkarak ve adaletle emrederse bundan dolayı onun için sevap vardır. Ĕ̆er bunun dışında emrederse bundan dolayı günahı da onadır" (Buharî, Cihad, 109; Müslim, İmâre, 53). Başka bir hadiste de: "Kıyamet günü, insanların Allah'a en sevgili ve mekân olarak en yakın olanı, âdil imamdrr. Kiyamet günü, insanların Allah'a en menfuru, O'ndan mekân olarak en uzak olanı da zâlim sultandır" (Tirmizî, Ahkâm, 4) buyurarak imamlık yapmayı adaletli olma, Allah'tan korkma şartına bağlamıştır.

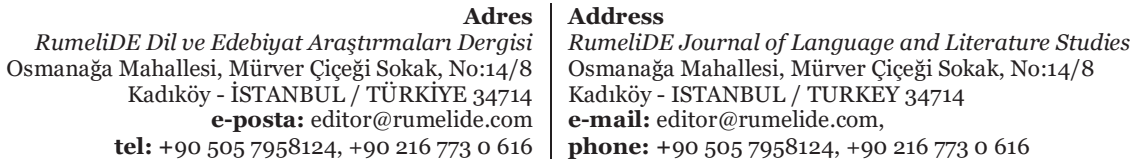


"İmam" kavramının, "cemaate namaz kıldıran" manasında geçtiği hadislere örnek olarak, "İmam, farz kıldığı yeri değiştirmeden aynı yerde nafile namaz kalmamahdır" (es-Sicistanî, Salât, 73/616); "İmam namazı kllp teşehhüdü tamamladıktan sonra, selam vermezden önce hades vaki olsa (yani abdesti bozulsa), namazı tamamlanmıştır, namazım tamamlayan cemaatteki diğer kimselerin namazı da tamamlanmıştır" (Ebu Davud, Salât, 74; Tirmizî, Salât, 300) hadisleri verilebilir. Cemaate namaz kıldıran imamların da cemaatin önderi mesabesinde oldukları unutulmamalıdır.

Ayrıca Kur’ân-ı Kerîm’de olduğu gibi hadis-i şeriflerde de "imam" kavramı "yol gösterici” (İbn Hanbel, 4/96) manasında da kullanılmıştır. Hz. Muhammed (s.a.v) döneminde imam kavramı, yukarıdaki hadislere göre cemaate namaz kıldıran manasında kullanılmıştır. Daha sonraki dönemlerde ise "imam" kavramı, cemaate namaz kıldıran manasının yanı sıra bir topluluğun önderi, yol göstericisi, devlet başkanı anlamında; özellikle hilâfetin Hz. Ali’ye intikalinden sonra devlet başkanı görevini yürüten, insanlara önderlik yapan anlamlarında kullanılmıştır. Kavram, itikadî ve amelî mezheplerin ortaya çıkışıyla birlikte de mezhep kurucusu veya bir mezhebe öncülük eden kişi şeklinde yeni anlamlar kazanmıștır.

\subsection{Sultân}

Münferit manalı liderlik ifade eden kavramlarından başka biri de "Sultân" kavramıdır. Sultân, Arapça "S-L-T سلط" kökünden tekili "sultân سلططين" olan türemiş bir kelimedir. Sultân, kelime olarak sözlükte; "padişah, vali, hüccet, burhan, delil, kuvvet” (İsfehanî, I, 2011:314) manalarına gelmektedir. Terim olarak "İslâm dünyasında XI. Yüzylldan itibaren (özellikle Selçuklularla birlikte) genellikle hükümdar ve devlet başkanları için Kur'ân'daki manalarından alıntılanarak kullanılmaya başlayan bir unvandır" (Özgüdenli, 2009:496). Ancak kelime, sonradan kazandığı bu anlamıyla Kur’ân'da kullanılmamıştır. Kur'ân-1 Kerîm'de "sultânin سلطانٍ" şeklinde yirmi bir, (Kur'ân, 7/71; 10/63; 11/96; 12/40; 14/10-11-22; 15/42; 16/99; 17/65; 18/15; 23/45; 27/21; 37/30156; 40/56; 44/19; 51/38; 52/38; 53/23; 55/33), "sultânen اسطاناً şeklinde on bir (Kur'ân, 3/151; 4/91-144-153; 6/81; 7/33; 17/3380; 22/71; 28/35; 30/35, "sultânuhu سلطانه" şeklinde bir (Kur’ân, 16/100), "sultâniye şeklinde

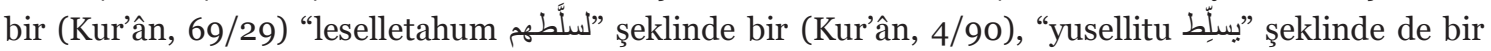
yerde (Kur'ân, 59/o6) olmak üzere toplam otuz yedi yerde geçmektedir.

Kur'ân'da "sultân" kelimesi, geçtiği yerlerin hepsinde "hüccet, burhan, delil, kuvvet, hâkimiyet" anlamlarında kullanılmıştır. Ayette "sultâniyeh" şeklinde geçtiği yerde ise mana; "mal, mülk, makam" anlamındadır. Görüldüğü üzere Kur'an'da Sultân kelimesi, dört temel kavramsal manayı ifade etmektedir. Bu kavramlar: Nüfuz, güç, iktidar; delil, kanıt; ferman, izin ve yetkidir.

Sultân kavramı, hadis-i şeriflerde de; “yönetici, devlet başkanı, sahip olunan mülk” manalarında kullanılmaktadır. Aşă̆ıdaki hadislerde "sultân" kavramının manasına ışık tutacak örnek kullanımlar yer almaktadır.

Hz. Muhammed (sav) buyurdular ki: "Cemaate, Kitabullah'ı en iyi okuyan kimse imam olur. Ĕger krraatte (okumada) herkes eşitse, sünneti en iyi bilen; sünneti bilmede eşitseler, hicret etmede evvel olan; hicrette de eşitseler, yaşça büyük olan imam olur. Kişi misafir olduğu evin sahibine veya (emri altında çalıştığı) sultânına imamlık yapmasın, ev sahibinin başköşesine izni olmadan da oturmasın." (Müslim, Mesacid, 29) Görüleceği üzere burada sultân, emri altında çalışllan kimse anlamında kullanılmıştır.

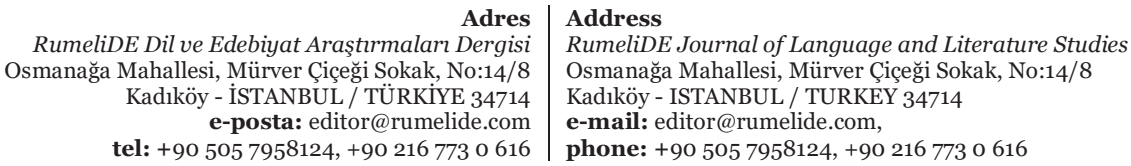

RumeliDE Journal of Language and Literature Studies

Osmanağa Mahallesi, Mürver Çiçeği Sokak, No:14/8

Kadıköy - ISTANBUL / TURKEY 34714

e-mail: editor@rumelide.com,

phone: +90 5057958124, +90 2167730616 
Sultân kavramının devlet başkanlı̆̆ı manasında kullanımına örnek hadiste ise şöyle buyurulmuştur: Rasûlullah (s.a.v.)'a bir adam gelerek: "Ey Allah'n Rasûlu! Bir adam gelip malımı almaya kalkarsa (ne yapayım)?" dedi. "Ona Allah'ı hattrlat!" cevabın verdi. Adam tekrar: "Hattrlamazsa ne yapayım?)" dedi. Allah’in Rasûlu: "Etrafindaki Müslümanlardan yardım talep et!" buyurdu. Adam: "Etrafimda hiç Müslüman yoksa ne yapayım?" dedi. "Öyleyse sultândan yardım iste!" buyurdu. Adam: "Sultân benden uzaksa?" dedi. Allah'in Rasûlu: "Bir ahiret şehidi oluncaya veya malın koruyuncaya kadar malın için mücadele et!" buyurdular (Nesâî, Tahrîm, 21). Anlaşlacağı üzere bu hadiste sultân, yönetici, erk sahibi anlamında kullanılmıştır. Başka bir hadiste Rasûlullah (s.a.v.) buyurdular ki: "Hz. Süleyman Beytu'l-makdis'i bina ettiği zaman, Allah'tan kendisine üç imtiyaz vermesini istedi: İlahi hükme müsadif olacak (uygun düşecek) hüküm (verme kapasitesi) talep etti; bu ona verildi. Kendisinden sonra kimseye verilmeyecek bir saltanat talep etti; bu da ona verildi. Mescidin inşaatın bitirdikten sonra bu mescide surf namaz kılmak için gelenlerin oradan çıkarken, annelerinden doğdukları gündeki gibi bütün günahları affedilmiş olarak çımalarını yalvardı; bu duası da kabul edildi" (Nesâî, Mesâcid, 6,2,34). Sultân, burada da mevki, makam manasında kullanılmıştır.

Görüleceği üzere "sultân" kavramı Kur'ân ayetlerinde "delil, burhan" manasında; yukarıda zikredilen hadislerde ve sözlüklerde daha çok "devlet başkanı, yönetici, mevki-makam, sahip olunan mülk" anlamlarında kullanılmıştır. Ancak burada dikkatlerden kaçmaması gereken bir husus vardır. Kaynaklarda, Halîfe ile Sultân veya halîfe-imam ile melik-sultân kavramlarının birbirinden farklı olduğu ve bu farkın da Allah'ın insanlara bildirmiş olduğu ilkeler çerçevesinde bir yönetim tarzı sergileyen ile buna ters bir yönetim tarzı sergileyen şeklinde bir anlam farklılığından kaynaklandığına vurgu yapılmaktadır. Bu yüzden istişare ile seçilen ve Kur'ân'da belirtilen ilkeler çerçevesinde devleti yöneten kişilere halîfe-imam denildiğini; bu ilkelere ters bir şekilde seçilen ve devleti dünyevî gayelerle yönetenlere ise sultân veya melik (kral) (İslâmoğlu, 2009:40-41) denildiğine vurgu yapılmaktadır.

Bu sebeple olsa gerek dikkat edilirse "imam" kavramıyla birlikte "adalet"; "sultân" kavramıla birlikte "zulüm” sıfat olarak zikredilmektedir. Çünkü "sultân” kelimesinin; dünyevileşen, olumsuz bir takım vasıflar layık görülen yöneticiler için sonradan kullanılmaya başlanan bir sıfat olduğuna kaynaklarda vurgu yapılmaktadır.

\subsection{Melik}

Münferit anlamlı lider kavramlarından bir değeri de "melik" kavramıdır. Melik, "M-L-K 近场" kökünden türemiş bir kelime olup çoğulu "mülûk ملوك" şeklindedir. Sözlükte "sahip olmak, malik olmak" (Güner, 2004:51-53); "bir ümmet, kabile veya ülkeyi kontrol altında tutan, emir verme yetkisine sahip kimse"; “على" cer harfi ile kullanıldığında "nüfuz-otorite sahibi olan” anlamlara gelmektedir (İbrahim Enis, 1972:886). Terim olarak melik; "hükümdar, kral, bir şehir veya bölgenin idaresiyle görevli hanedan mensubu, yüksek devlet görevlileri için kullanılan bir unvan", (Güner, 2004:51) "bir halkın yönetim işlerini üstlenip onlar üzerinde emretme ve yasaklama tasarrufunda bulunan kimse" (İsfehanî, 2011:775) anlamlarina gelmektedir.

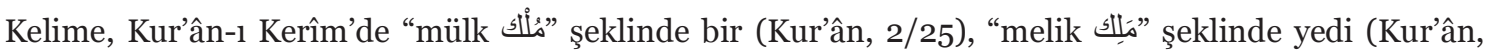

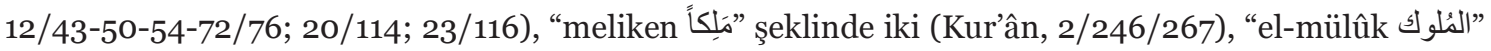

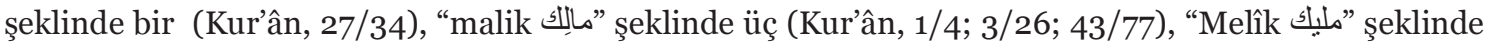

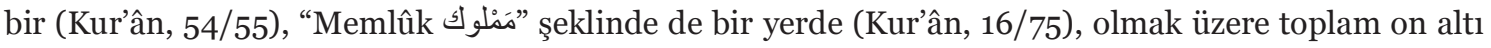
yerde aynı kökten türeyen farklı biçimlerde geçmektedir.

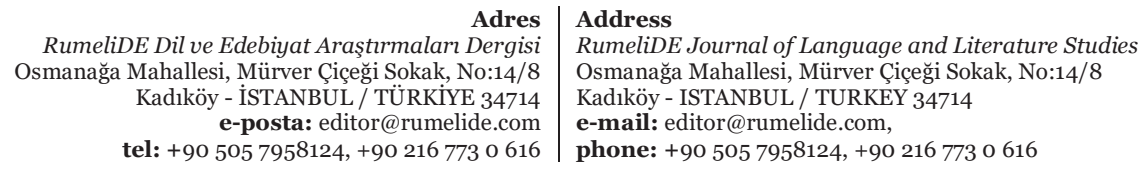


Kur'an'da melik kelimesinin, bir yandan "evreni yöneten Allah'ın sıfatı" (Kur'ân, 114/1-2) olarak, öte yandan da "insanları yöneten hükümdar"(Kur’ân, 12/76) anlamlarında kullanıldı̆̆ı görülmektedir (Akyüz, 1997: 140). Kur'ân'daki aynı ayırıma Mâverdî de dikkat çekmektedir. Mâverdî melik kavramı konusunda; “Kur'ân-ı Kerîm'de Allah hakkında kullanıldığı gibi dünya hükümdarları (âdil-zalim; mümin-kâfir hükümdar)" için de kullanılmaktadır (el-Maverdî, 2004: 67) diyerek konuya açıklık getirmeye çalışmıştır.

Ancak Kur'ân'da, melik sıfatının peygamberler için hiç kullanılmadı̆̆ı, insanların hükümdarlı̆̆ i için kullanıldığında da bazen olumlu çoğu kez olumsuz çağrışımlar uyandıracak bağlamlarda kullanıldığı görülmektedir.

Melik kavramının, hem Allah hem de devlet başkanı olan kişiler hakkında kullanılması adeta kâinatın asıl hükümdarı olan Allah'ın yeryüzünün hükümdarlı̆̆ını kendisine verdiği insanın Allah'ın vekili olduğunun güzel bir kanıtıdır. Çünkü Allah tüm kâinatın gerçek mâliki insan ise yeryüzünün geçici mâlikidir şeklinde çıarım yapmak mümkündür.

Melik sıfatı içerdiği olumsuz anlam nedeniyle olsa gerek ilk dönem İslâm devlet geleneğinde hükümdar, sultân manasında kullanılmamıştır. Emevî Devleti’nin yöneticilerinin, devlet başkanlığını verasete dayalı bir sistem haline getirmek gibi mutat olmayan bir işe başlamaları sebebiyle melik sıfatını ilk defa kullanmaya başladıklarını dile getirenler (Güner, 2004:51-53) de vardır.

"Melik" çoğulu "mülûk" kavramı, hadislerde de "devlet başkanı, yeryüzünde idarecilik yapan kişi, bir yere hükümran olan” manalarında kullanılmaktadır. Melik kavramının; liderlik, yöneticilik, devlet başkanlığı manalarında zikredildiğini aşağıdaki hadislerde görmek mümkündür.

Rasûlullah (s.a.v.), buyurdular ki: "Allah Teâlâ yeryüzünü kabzeder, sağ eliyle de gökyüzünü dürer. Sonra der ki: melik benim, yeryüzünün melikleri nerede?” (Buharî, Tefsir, 39/3) başka bir hadiste Rasûlullah(s.a.v.) buyurdular ki: "Mülk (saltanat, idare) Kureyş'tedir. Keza (davaları hükme bağlama) Ensar'dadır. Ezan Habeşlilerdedir, emânet (güven) Ezd'dedir, yani Yemen'dedir"(Tirmizî, Menâkib, 72).

Görüleceği üzere “melik” çoğulu "mülûk” kavramı, Kur'ân'da, hadislerde ve sözlüklerde Allah için kullanımı söz konusu olduğunda; topyekûn evrenin ve âlemlerin tek sahibi, onlar üzerinde her türlü tasarrufa sahip, sevk ve idare eden anlamında kullanılmıştır. Ancak insanlar için söz konusu olduğunda melik, yeryüzünde devletler, topluluklar ve insanların yöneten; insanların sorumluluklarını üstlenip onlar üzerinde hükmetme tasarrufunu, yetkisini elinde bulunduran kimse anlamlarını ifade etmek için kullanılmıştır.

\subsection{Emîr}

Münferit anlamlı liderlik ifade eden kavramlardan başka biri de "emîr" kavramıdır. Kur'ân'da direkt olarak "Emîr أمير" kavramı geçmemektedir. Ancak aynı kavramın kökü "E-M-R أمر " olan kelime pek çok ayette farklı lafız ve anlamlarda zikredilmektedir.

Emr sözlükte; "iş, olgu, ruh, durum, olay; hüküm, emir" anlamlarına gelmektedir (İsfehanî, 2011:89). Emr terim anlamı bakımından ise; "birisine yapması için söylenen iş; bir işin yapılmasının istendiğini ifade eden söz, buyruk, istek" (İsfehanî, 2011:89) anlamlarına gelmektedir. Emîr kelime olarak sözlüklerde, emir verme yetkisi olan kral, vali, bir imâretin (prenslik) başına geçip emreden kişi

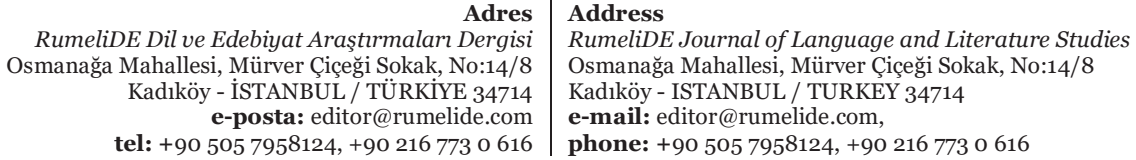


manalarına gelir (İbn Manzur, I, 127-128). Emîr, kavram olarak ise "dört Halîfe döneminde cemaat başkanı, devlet başkanı, sonraları ordu komutanı, fetihleri gerçekleştiren vali” (ed-Dürî, 1995:121-123) manalarında kullanılmıştır.

Kavram Kur'ân'da, “iş, durum, olgu, olay, hal" manasında toplam yirmi dokuz yerde (Kur'ân, 2/210; $3 / 128,152,154,159 ; 6 / 8,58 ; 8 / 43 ; 9 / 48 ; 10 / 3,31 ; 11 / 44,73,123 ; 12 / 41 ; 14 / 22 ; 16 / 77 ; 17 / 85 ; 19 / 39$; 22/67; 24/62; 32/o5; 44/04; 47/21, 26; 49/7; 50/5; 54/3,12; 97/4), "buyruk, hüküm, emir, din" anlamında ancak aynı kökten olup farklı kelime kalıplarında toplam kırk yedi yerde (Kur'ân, 2/8; 4/47,60; 5/52; 6/71; 7/54, 77, 150; 9/31,106; 11/43,59,76,97,101,112; 13/11,31; 15/65,66,94; 16/1,33,50; $18 / 50 ; 19 / 64 ; 26 / 151 ; 27 / 33 ; 28 / 44 ; 30 / 4 ; 33 / 37,38 ; 37 / 102 ; 40 / 78 ; 42 / 15 ; 45 / 7,18 ; 46 / 25 ; 49 / 9$; 51/44; 57/14; 65/5,8,12; 66/6; 82/19; 98/5) geçmektedir. Lafız olarak "Emîr" kavramı Kur'ân'da geçmemekle birlikte hadislerde; "komutan, vali, kabile reisi, prens" manalarında kullanılmıştır (İbn Manzur, I, 125). İslâm'ın ilk dönemine ait kaynaklarda âmil kelimesi emîr ile eş anlamlı olarak sıkça geçmektedir. Hz. Peygamber’in vefatı üzerine Ensar ve Muhacirlerin Halîfe seçmek için Sakifetü Benî Saîde'de yaptıkları toplantıyla ilgili rivayetlerde Müslüman cemaatin başkanı için "emîr" tabiri kullanılmıştır (Taberî, 1967: 1840-1841). Daha sonra Hulefâi Râşidin döneminde bu kavramın devlet başkanı manasında sıklıkla kullanılan bir unvan olduğu görülmektedir.

Emîr kelimesinin "devlet başkanı, kabile reisi, kral" manasında kullanıldı̆̆ı hadislerden birkaç tanesi şu şekilde rivayet edilmektedir. Rasûlullah (s.a.v.) buyurdular ki: "Size emirlerinizin en hayırlılar kimlerdir, en şerirleri kimlerdir haber vereyim mi? Onlarn en hayırlları sizlerin sevgisine mazhar olanlar sizleri sevenlerdir; lehlerinde hayırla dua edersiniz, onlar da size hayır dua ederler. Ümeranızın şerirleri de sizin buğz ettiklerinizdir, onlar da size buğz ederler, siz onlara lanet edersiniz, onlar da size lanet ederler"(Tirmizî, Fiten, 77). Bir diğer hadis-i şerifte Hz. Muhammed (s.a.v.): "Rasûlullah (a.s.) Mute Savaşı'nda Zeyd b. Harise (r.a)'ı emîr (komutan) tayin etti ve dedi ki: "Ĕger Zeyd öldürülecek olursa, komutan Cafer'dir. Cafer öldürülecek olursa Abdullah İbnu Ravaha'drr" (r.a). Abdullah der ki: "Bu savaşta aralarnda ben de vardım. (Bir ara) Cafer b. Ebi Talib (r.a)'ı aradık. Onu ölüler arasında bulduk. Öyleydi ki cesedinin ön cephesinde doksan küsur ok ve mızrak yarası saydlk." Bir rivayette de şu ziyadeyi ilave etmiştir: "Arka tarafinda hiç yara yoktu"(Buharî, Meğazî, 44) Rivayette "emir" kavramını ordunun başında bulunan komutan anlamında kullandığ anlaşılmaktadır.

Yönetici manasında "emîr" kavramının kullanılmasına örnek olması bakımından aşağıdaki hadisler örnek olarak verilebilir.

"Ebu Musa dedi ki; Yanımda amcamm evlatlarmdan iki kişi daha olduğu halde Rasûlullah (s.a.v.)'in huzuruna girdim. Yanımdakilerden biri: "Ey Allah'ın Resulü! Allah'ın sana tevdi ettiği işlerden bazıları üzerine bizi emir tayin et" dedi. Diğeri de ayn talepte bulundu. Rasûlullah (s.a.v.)'ın onlara cevabı şu oldu: "Biz, Allah'a kasem olsun, bu işe, onu talep eden veya ona hrrs gösteren hiç kimseyi tayin etmeyiz!" (Buharî, Ahkâm,12, İcâre 8, İstitâbe 2; Müslim, İmâret,7). "Emîr" kavramı bir diğer hadiste de aynı manada geçmektedir: "Rasûlullah (s.a.v.) buyurdular ki: "Ey Abdurrahman! Emirlik isteme. Eğer senin talebin üzerine sana emirlik verilirse, istediğin şeyin sorumluluğu sana yüklenir. Ĕ̆ger sen talibi olmadan sana emirlik verilirse, o işte yardım görürsün. Bir iş için yemin eder, sonra da aksini yapmakta hayır görürsen, daha hayırlı gördüğün ne ise onu yap, ettiğin yemin için de kefarette bulun"( Buharî, Ahkâm 5, 6, Eyman 1; Müslim, İmâret 19, Tirmizî, Nüzur 5).

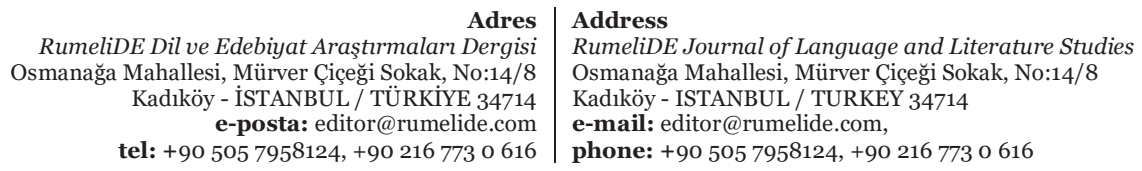


"Emîr" kavramının, sözlük ve hadis-i şeriflerde; devlete ait herhangi bir işi yürütme konusunda emir etme yetkisini elinde bulunduran, devletin başkanı, bir mevki makam sahibi olup emretmekle mükellef kişi, komutan, vali anlamlarında kullanıldı ̆̆ı anlaşılmaktadır.

\subsection{Râ'î}

Tek başına lider anlamındaki kavramlardan bir başkası da "râ’ı̂" kavramıdır. Arapça 'da (r-â-y; رعى) kökünden türeyen (râ’î راعي) kelimesi sözlükte; "sürüyü gütmek, çobanlık etmek, gözetmek, kollamak, bakmak, bir şeyden sorumlu olmak" (Enis, 1972:356) anlamlarına gelmektedir. Terim olarak; "sorumluluğu altında bulunan şeyleri korumak, sorumlu olduğu insanları yönetmek, gözetmek" manalarına gelmektedir (İsfehanî, 2011:262). Ancak "râ’î ر اعي" kavramı, Kur’ân-ı Kerîm'de bu şekliyle geçmemektedir. Buna karşın hadis-i şeriflerde bizzat yukarıda verilen anlamıla geçmektedir. Örneğin bir hadis-i şerifte Hz. Muhammed (a.s.) şöyle buyurmuşlardır: "Hepiniz çobansınız ve her çoban güttüğü ile mesuldür" ( Buhârî, Cum'a 11, İstikrâz 20, Itk 17, 19, Vasâyâ 9, Nikâh 81, 90, Ahkâm 1; Müslim, İmâret 5; Ahmed b. Hanbel, 2/5 , 2/54). Başka bir hadiste Hz. Muhammed (s.a.v.) râ'î kelimesinin farklı anlamlara geldiğini gösterecek şekilde şöyle buyurmuştur: "Hepiniz çobansınız ve hepiniz sürünüzden mesulsünüz. İmam çobandır ve sürüsünden mesuldür. Erkek ailesinin çobanıdır ve sürüsünden mesuldür. Kadın, kocasmm evinde çobandır, o da sürüsünden mesuldür. Hizmetçi, efendisinin malından sorumludur ve sürüsünden mesuldür." İbnu Ömer der ki: "Bunları Rasûlullah (a.s.)'tan işitmiştim. Zannediyorum ki şöyle de demişti: "Kişi babasının malında çobandır, o da sürüsünden mesuldür"(Buharî, Ahkâm, 1, Cum'a, 11, İstikraz, 20, Itk, 17, 19, Vesaya, 9, Nikah, 81, 90; Müslim, İmâret, 20; Tirmizî, Cihad, 27; Ebu Davud, İmâret, 1).

Görüleceği gibi hadislerde "râ’î; ربع" kelimesi; sorumlu olduklarını yöneten, bakmakla yükümlü olduklarından sorumlu, sorumlu olduklarına önderlik, liderlik eden, yönettiklerinden sorumlu kişi anlamlarında kullanılmıştır. Burada dikkat edilmesi gereken husus şudur. Sorumlu olunan şey; bazen ev halkı, bazen güdülecek hayvanlar, bazen idare edilecek mal-mülk, servettir. Dolayısıyla râ'î, yani sorumlulukları bulunan herkes bir tür liderdir ve bundan dolayı her insan yaşamı boyunca bu sorumluluklardan bir veya bir kaçını üstlenmekte ve bu yüzden de râ’î sıfatını ve rolünü alabilmektedir. Buradan da şu sonucu çıkarmak mümkündür. Üzerinde ne tür sorumluluk olursa olsun, sorumluluk sahibi herkes râ'î yani idare eden, yöneten, koruyan, kollayan, gözetleyen ve buna uygun hareket eden liderdir.

\section{Sosyal bir sınif veya grup olarak liderler}

Kur'ân'da münferit olarak değil de topluluk/grup olarak emâneti üstlenen yani yönetim erkini elinde bulunduran kimseler anlamına gelen bir takım isimler de vardır. İçinde bulundukları topluma yön veren, o toplumun sevk ve idaresini sosyal bir topluluk/sınıf halinde yürütenleri işaret eden ve o topluluğun bir takım özelliklerinden bahseden lafızlar mevcuttur. Bunlardan ilki "kebîr” lafzıdır.

\subsection{Ekâbîr}

Kelime Arapça (K-B-R كبر) kök harflerinden türeyen ve çoğulu; "ekâbir أكابر ve küberâ "كبر " olan kelimenin tekili "kebîr كبير" şeklindedir. Kebîr, sözlükte; "büyük, önder, kocaman, nüfuzlu, başkan, üstün, yaşlı, büyük günah” anlamlarına gelmektedir (el-İsfehanî, 2011:544). Kavram olarak; bir kavmin büyükleri, önderleri, ileri gelenleri, beyleri, liderleri anlamlarına gelmektedir (İbn Manzur, V,3710).

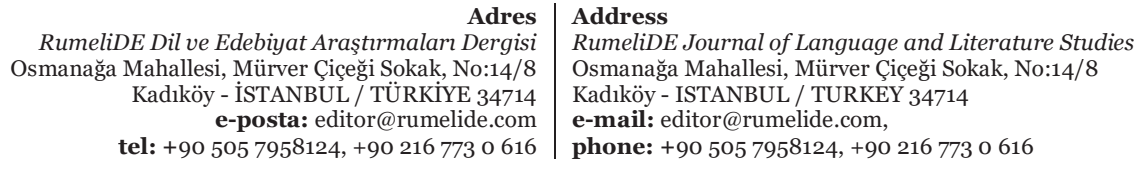


Kebîr kelimesi, Kur'ân-ı Kerîm'de, “ağabey” manasında dört (Kur'ân, 12/80; 20/71; 21/63; 26/49); "kavmin önderleri, büyükleri" manasındaki "küberâ" kelimesi bir (Kur'ân, 33/67); "ileri gelenler, liderler" anlamına gelen "ekâbîr" kelimesi bir yerde (Kur'ân, 6/123) olmak üzere toplam altı yerde geçmektedir.

Kebir kelimesi Yusuf Suresi’nde ağabey manasında kullanılmıştır: "Büyükleri dedi ki: Babanızın daha önce de sizden Allah adına söz aldığını, Yusuf hakkında işlediğiniz kusuru biliyor musunuz?” (Kur'ân, 12/80) Tefsir kaynaklarının çoğunda ayette geçen kebîr kelimesi büyük kardeş, ağabey anlamında kullanılmıştır. Allah, En’am Suresi’nde şöyle buyurmuştur: "Böylece biz her kasabada orada bozgunculuk yapmaları için, günahkârların liderler yaptık...” (Kur’ân, 6/123). Burada kebir kelimesiyle aynı kökten gelen "ekâbir" kavramı liderler, toplumun önde gelenleri manasında kullanılmıștır.

Hadis-i şeriflerde de "kebîr-küberâ" kavramı; "ileri gelenler, büyükler, bir kavmin yaşlıları, önderleri, büyükleri" manalarında kullanılmıştır (Ahmed b. Hanbel, 4/3). Ayrıca "kebîr", "küberâ", "ekâbîr", kavramlarının pek çok hadiste "yaşça ileri gelenler" manası kastedilerek kullanılmıştır (Ebu Davud, Diyat, 8).

Kebîr, küçüğün zıddı olarak düşünüldüğünde yaşça büyük olarak da anlaşılabilir. Şarklı toplumların geleneklerinde ister ailede olsun ister en küçük sosyal yapılarda olsun söz söylemede, yönetmede hak ve yetki yaşça en büyük olanındır. Bu ilke pek çok doğulu toplumda hala pek çok alanda gayri resmi uygulanmaktadır.

Anlatılanlardan hareketle "Ekâbîr-kübera" kavramlarının Kur'ân ve sünnette; bir topluluğu, bir kavmi sevk ve idare eden, onun başında bulunan, onu yöneten kişi veya kişiler manasında kullanıldığı açıkça görülmektedir.

\subsection{Mele'}

Sosyal bir sınıf olarak yönetme erkini elinde bulunduran anlamdaki lafızlardan biri de "mele" lafzıdır. Mele', "M-L-E ملأ kökünden türemiş bir mastar olup çoğulu "emlau أملاء" şeklinde gelmektedir.

Sözlükte; doldurmak, dolmak, bir kimseye yardım etmek, kurulan yayı iyice germek, zengin olmak gibi manalarının yanı sıra heyet, topluluk, bir gurup insan, cemaat, dinleyiciler, ileri gelenler, ekâbîr, anlamlarına da gelir (Firuzabadî, 1993: 29). Mele' kelimesi, müşavere heyeti, idarecilik için toplanmış heyet manalarında da gelmektedir (Zebidî, 1984: 119). Bu anlamda kullanıldığına dair örnek Ebu Süfyan (ö., 652)'n şu cümlesidir: Mekkeli müşrikler Uhud Savaşı'nda Bedir Savaşı'nın intikamını almak için şehitlerin organlarını kesmişlerdi. Ebu Süfyan, tasvip edilmeyen bu hareketi kendine danışılmadan yapıldığını anlatmak için (غير ملا الناس insanlara danışılmadan) ifadesini kullanmıştır (Ahmed b. Hanbel, I,463). Cemaat topluluk manasındaki kullanımına da ( على ملا الناس insanların, cemaatin, topluluğun gözü önünde) cümlesi örnek gösterilebilir (İbn Manzur, I,159). Terim olarak mele'; Bir toplumun eşrafi, ileri gelenleri, önderleri, asilzadeleri, soyluları, aristokrat tabakası, fikir danışılan kimseleri, beyleri, yöneticileri, kodamanları demektir. Erkân, kurmaylar, elebaşları, iktidar seçkinleri olarak da düşünülebilirler (Akyüz, 1997:191).

Mele' kavramının geçtiği En'am Suresi'nin 52'nci ayetinin nüzul sebebi ile ilgili rivayetlerde de (birbirleriyle farklılık arz etmelerine rağmen) bu kavramın; bir kavmin eşraf ve uluları (el-Endülüsî, 1910: IV, 135), reisleri, beyleri (Taberî, 1967: VII,202) manalarında kullanıldığı görülmektedir. Bu

Adres Address

RumeliDE Dil ve Edebiyat Araştırmaları Dergisi Osmanağa Mahallesi, Mürver Çiçeği Sokak, No:14/8 Kadıköy - İSTANBUL / TÜRKIYE 34714 e-posta: editor@rumelide.com

RumeliDE Journal of Language and Literature Studies

Osmanağa Mahallesi, Mürver Çiçeği Sokak, No:14/8

Kadıköy - ISTANBUL / TURKEY 34714 tel: +90 5057958124, +902167730616 phone: +90 5057958124, +902167730616 
durumda belirtilen ayeti açıklamak için aynı nüzul sebebinin tamamını veya mefhumunu alan kaynaklara göre "mele" kelimesi, kavmin içinde sözü geçen kimseler, eşraf, bey ve reisler manalarıyla eş anlamlı sayllır.

Kelime, Kur'ân-1 Kerîm'de; "el-meleu الملأ "şeklinde yirmi (2/246; 7/60-66-75-88-90-105-127; 11/2738 ; 12/43; 23/24-33; 26/34; 27/32-38; 28/20-38; 37/08; 38/6-69), "mel'ehu هلأ " şeklinde bir (Kur'ân, 10/88), "meleihi ملاه" şeklinde altı (7/103; 10/75; 11/97; 23/46; 28/32; 43/46), "Meleihim "ملئهم (2)" şeklinde bir (Kur'ân, 10/83), "Mele-i A'la الملإ الاعلى" şeklinde iki yerde (Kur'ân, 37/8;38/69) olmak üzere toplam otuz yerde geçmektedir. Kur'ân-ı Kerîm'de "mele” yirmi sekiz yerde bir toplumun eşrafı, ileri gelenleri, önderleri, asilzadeleri, soyluları, aristokrat tabakası, fikir danışılan kimseleri, beyleri, yöneticileri, kodamanları anlamlarında kullanılmıştır. "Mele-i A'la" ise iki yerde en yüksek melekler, peygamberlerin ruhları, yüce meclis/topluluk anlamında geçmektedir (Akyüz, 1997:190).

Kur'ân'da Neml Suresi'nde mele' kavramı, devlet başkanının etrafında fikir danışmak için bulunan asilzadeler, soylular manasında da kullanılmıştır. Bu manayı; "Sonra Melike dedi ki: Beyler, ulular bu işimde bana fikir verin siz yanımda olmadan hiçbir işi kestirip atamam" (Kur'ân, 27/32) ayetinde görmek mümkündür. Kur'ân'da Mele' kavramın; inkârcılık-küfür; büyüklenme-alay; aşırı tutuculukkatı gelenekçilik niteliklerine haiz topluluk gurup şeklinde manalar yüklendiği de görülmektedir (Akyüz, 1997:79-80). Bunların, toplumun siyasî, ekonomik ve sosyal güç merkezlerini elinde tutan, katı gelenekçi bir grup olduğu anlaşılmaktadır.

Hadis-i şeriflerde de "mele" " kavramı; bir topluluğun önde gelenleri, fikir danışılanları manalarında kullanılmıştır. Buna örnek olarak şu hadis gösterilebilir. Rivayet edildiğine göre Rasûlullah (s.a.v.) Ensar'dan olup Bedir savaşından dönen birinin; "Yaşl kellerden başka kimseyle savaşmadık" dediğini duydu. Rasûlullah (s.a.v.) ona dedi ki: "Onlar Kureyş̧in eşrafidır (önderleri, liderleri, büyükleri)" (İbn Manzur, VI, 4552).

Mele', eşraf, bir kavmin yüksek mertebeli, kadri yüce, şerefli adamları anlamlarına da gelmektedir (Firuzabadî, 1993: I,29). Kelimenin bu anlamda kullanıldığını şu hadiste görmek mümkündür: "Bedir Savaşı'ndan zaferle dönen Müslümanlar Medine’ye vardıklarında sevinç ve coşkuyla karşılanmış, tebrik edilmişlerdi. Gazilerden Seleme b. Seleme zaferlerinin büyütüldüğünü kastederek şöyle der: "Bizi neden böyle coşkuyla tebrik ediyorlar? Hâlbuki biz siradan bir takım aciz ve yaşh kimseleri öldürdük". Peygamber efendimiz bunu duyunca tebessüm ederek: "Ey kardeşimin oğlu, onlar (öldürdükleriniz) mele' (eşraf, ileri gelenler ve liderlerdir) der” (İbn Hişam, II, 297).

Özetle "mele" kavramı; bir toplumun sosyal, siyasal ve ekonomik bakımdan ileri gelenleri, bulundukları toplumlarda imtiyaz sahibi, her konu hakkında sözlerinin dinlenilmesini, görüşlerinin alınmasını ve uygulanmasını isteyen, toplumun gidişatına yön verme hakkının kendilerinde olmasını isteyen ayrıcalıklı bir sınıf olarak tasvir edilebilir.

\subsection{Mütref}

Anlam bakımından mele kavramıyla birlikte zikredilmesi gereken sosyal bir sınıf olarak lider anlamı ifade eden bir diğer kavram da "mütref مترف" kavramıdır. Mütref, Arapça "T-R-F; ترف" kökünden türemiş bir kelimedir. Sözlükte; sulu oldu, bolluk içinde olmak, nimetlenmek (İbn Manzur, IX,17), refah, nimette bolluk (İsfehanî, 2011:73), (فعال ifâl) vezninde kullanılınca mana; nimetin, bolluğun azdırması (Zebidî, 1984: VI, 49), dilediğini yapan, men olunmayan, dünya lezzetlerinden ve şehvetlerinden bolca

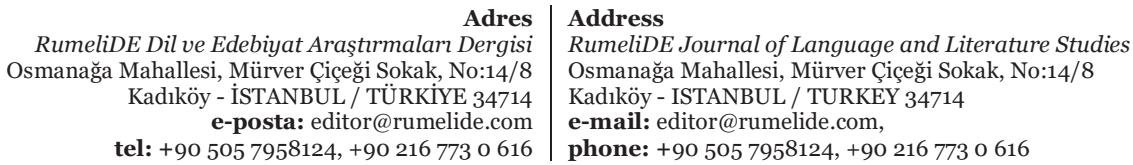


istifade eden (Zebidî, 1984: VI, 49), (استفعال istifâl) vezninde kullanılınca nimetin çokluğu nedeniyle azgınlık etmek, tuğyan, büyüklenmek (Firuzabadî, 1993: III,150) manalarına gelir. Örneğin Arapça'da birinin azgınlık ve sapkınlıkta ısrar ettiğini söylemek için (اذا أصر على البغي أنرفه فلان) şeklinde söylenir (Firuzabadî, 1993: III,150). Terim olarak; "bol nimete sahip olan, rahat içinde müreffeh bir hayat sürdüren, kendisine verilen bol nimetlere doymayan, tatmin duygusunu yitiren, pervasızlaşan, kimseden nasihat almaya yanaşmayan, azan, dünya nimetleri hususunda geniş bir bolluğa sahip kılındığı için bencil davranan, şımardıkça şımaran ve elde ettiklerine hükmetme konusunda aklı devreden çıkıp anlık hazlarının peşine düşen, mütekebbir olan kimse, terk edildiği için başına buyruk yaşayan insan tipi” anlamlarına gelmektedir (Yücedoğru, 2012:3-6).

Kur'ânda mütref kelimesi, sosyal bir sınıf olarak liderler anlamını ifade eden bir kavram şeklinde yer almaktadır. Çok fazla olmamakla birlikte "mütref" kelimesi tamamı Mekkî olan sekiz ayette (11/116; $17 / 16 ; 21 / 13 ; 23 / 33,64 ; 34 / 34 ; 43 / 23 ; 56 / 45$ ) geçmekte, bunların beş tanesi çoğul, diğer üç tanesi de fiil hâlinde zikredilmektedir.

Kur'ân-ı Kerîm, tekil şeklinde değil ama toplumda var olan bir grubu, nitelikleri ön plana çıkmış bir insan öbeğini; mütref topluluğunu konu edinmiş; sözü edilen bu insan öbeği: Tağuta tapanlar; küfür, inkâr, azgınlık ve inatları konusunda haddi aşan kimseler olarak nitelendirilmişlerdir (Yücedoğru, 2012:3-6).

Kur'ân'daki ayetlerin bağlamı incelendiğinde mütrefin; kavuşmuş oldukları nimetlerden dolayı kendilerini, başkalarına karşı sorumlu görmeyen, başkalarından bağımsız hatta yeryüzünde kendilerinden daha akıllı, güçlü, yetenekli kimse olmadığını düşünen, Allah’a karşı bile sorumlulukları yokmuş gibi davranan, Allah’a muhtaç olmadıkları vehmine kapılan, gaflet içinde yaşayan bir topluluğu ifade etmek için kullanıldı̆̆ı görülecektir.

Mütref grubuna dâhil olan kimseler önceden düşkün, muhtaç, zayıf olup sonradan mütref sınıfına girmişseler bu hallerini unutan, sonradan sahip oldukları her şeyin kendi akıl, yetenek ve bilgileriyle elde ettiklerini düşünenlerdir. Allah'ı ve insanlara gönderdiği emir ve yasakları unutup veya dikkate almayıp sefih bir hayat sürmeyi tercih edenlerdir. Bunlar, diledikleri gibi konuşan, hevâ heves ve ihtiraslarının peşine düşen, istediklerini elde etmek için her yolu mubah gören, bu konuda kural ve sınır tanımayan, hatta bununla da kalmayıp ilahlık taslayan ve yeryüzünde tanrı gibi hareket eden, kendilerinden olmayan insanlara da tepeden bakıp hor gören, aşağılayan ve insanlara kötü muamele eden; kendilerini her şeyin üstünde görüp heva ve heveslerini ilah edindikleri için kendilerinden son derece emin olan ve bundan dolayı da yaptıklarının da mutlak doğru olduğuna inanan bir yapıya sahiptirler.

İşte bu hal ve tavır içine girmiş insanlar, Kur'ân'da zikredilen sınırları aşan, isyankâr, zalim, insani özelliklerini yitirip daha çok hayvani özellikleri ile ön plana çıkan şahsiyetlerdir. Bu özellikleri dolayısıyla diğer normal insanlardan ayrılırlar. Zevk-ü sefa içinde yaşarlar ve ait oldukları toplumun değer yargıları ve kurallarını hiçe sayarlar. Toplumun kural ve değer yargılarını toplumun ilerleyip gelişmesi için engel görürler.

Mütref zümresine dâhil olanlar, bulundukları toplumdaki sosyo-ekonomik seviyelerinin, içinde doğdukları ailelerinin soyluluk ve şerefinden kaynaklandığına inanırlar. Bundan dolayı geçmişten miras aldıkları sermaye, liderlik ve yönetim tecrübeleri dolayısıyla siyaset, sermaye ve idarede herkesten daha

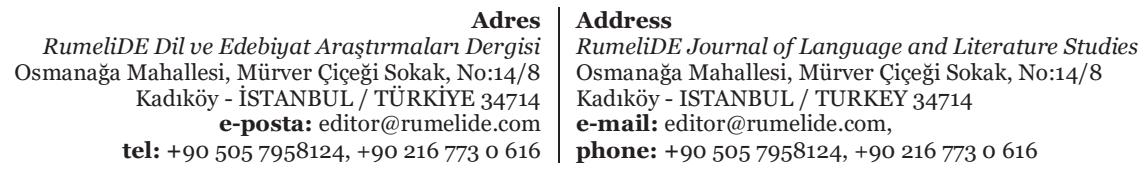


fazla söz hakkına sahip olduklarına inanırlar, bu yüzden kimseden akıl, emir ve tavsiye almaya alışkın değillerdir.

Bu anlamda aslında mele' ile mütref kavramları anlam ve işlev bakımından birbirine benzemektedir. Mütref kavramı, yalnızca zenginlik, soyluluk ve üstünlüğü daha sonradan görüp şımarmış, kendi olmaktan çıkmış bir topluluk olma yönüyle mele' kavramından ayrılmaktadır. Çünkü mele’ kavramı sözlük anlamı bakımından, görüşüne başvurmak için kendisine müracaat edilen manasına haiz iken, mütref kavramı sözlük anlamı itibariyle nimetlerden dolayı azmış, şımarmış, isyankâr olma manası daha fazla ön plana çıkan bir kavramdır.

Bu mülahazalar neticesinde; "mütref" için toplumlarda kendi çlkarları doğrultusunda organize bir şekilde hareket eden ancak içinde bulundukları toplumun geneli için olumsuz davranış ve düşünüşleri bakımından ters olan etkin bir topluluktur denilebilir.

Sahih-i Buharî'de "mütref” kavramının içinde geçtiği bir hadis rivayet edilmektedir (Buharî, Tevhid, 24) ve "mütref" kavramı bu hadiste tıpkı Kur'ân ayetlerinde kullanıldığı manasıyla kullanılmaktadır (Müslim, İman, 347).

Görüleceği üzere ayet, hadis ve sözlüklerde mütref; içinde bulundukları toplumda yönetim erkini ellerinde tutan, imtiyaz sahibi, nüfuzlu, kendilerine göre değer sistemleri bulunan, toplumdaki önderlik yetki ve hakkının kendi doğal hakları olduğuna inanan, bolluk ve refah içinde şımarmış, azmış bir topluluk anlamlarina gelmektedir.

\subsection{Nakib}

Sosyal bir zümre olarak liderlik anlamı ifade eden başka bir lafız da "nakib" kavramıdır. Arapça "N-KB نقب" kök fiilinden türeyen çoğulu "nukebâ نقباء" olan "nakîb نقيب) kelimesi tekil bir sifattır. Sözlükte hayırlı seçkin kişi, bir topluluğun başkanı, vekili, kefili, emini (Uyar, 2006:321), bir topluluğun büyügü̈, kaptan rütbesi, orduda bir rütbe (Enis, 1972: I,944), ayrıca başka bir millete ait haberleri öğrenen, teftiş eden, öğrendiklerini kendi milletine aktaran bir nevi casus" anlamlarına gelmektedir (Akyüz, 1997:9). Terim olarak nakîb; siyasî, içtimaî, askerî, dinî alanlarda hükümdar veya şeyhlerin maiyetinde görevli üst düzey sorumlularını ifade etmektedir. Bu manalarının yanı sıra Hz. Fâtıma ile Hz. Ali’nin neslinden gelen seyyid-şeriflerin meseleleriyle ilgilenmek üzere devlet tarafından tayin edilen memura da bu unvan verilmiştir (Uyar, 2006:321).

Kur'ân-ı Kerîm'de "nakîb" kavramı sadece bir yerde geçmektedir: "And olsun ki, Allah, İsrail Oğullarından söz almışt. Onlardan on iki reis-gözetici gönderdik..... ” (Kur'ân, 5/12) Nakib kavramı; bu ayette ; "reis, başkan, önder, temsilci, gözetleyici" manalarında kullanılmıştır.

Hadis-i şeriflerdeki kullanımlarına bakıldığında, "nakîb" kavramının; liderin, reisin yardımcısı, yardımcıları, bir topluluğun veya kabilenin reisi veya vekili, gözetleyicisi anlamlarında kullanıldığı görülmektedir. Bu anlamda kullanıma: Hz. Peygamberin: "Benden önceki nebilere yedi nakîb, vezîr, necîb verilmiştir. Ancak bana yedisi Kureyş’ten, yedisi muhacirinden olmak üzere on dört vezir, nakîb, necîb verilmiştir" (Ahmed b. Hanbel, I, 88) hadisi örnek olarak verilebilir.

Zikredilen hadislerden anlaşılan o ki "nakîb" kavramı; "yardımcı" manasına da gelmektedir. Gerek Kur'ân ayetleri gerek hadisler ve gerekse sözlük anlamları gözden geçirildiğinde nakîb kavramı; bir

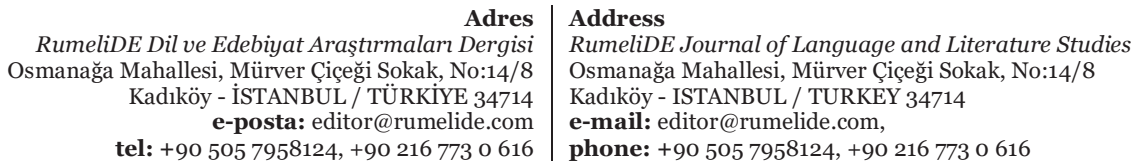


topluluğun, gurubun başkanı, vekili manasının yanı sıra bir liderin yardımcısı, lider veya aynı konumdaki kişilerin işlerinden sorumlu kişi/kişiler gibi anlamlar içermektedir.

\subsection{Seyyid/Sâdât}

Sosyal bir sınıf şeklinde liderlik ifade eden başka bir kavram da "Sâdât" kavramıdır. "Sâdât" kavramı Arapça'da, "S-V-D" kök harflerinden türeyen "seyyid "سيّّ" kelimesinin çoğulu olan bir sıfat isimdir. Sözlükte; efendi, mülk sahibi, reis, koca ve ulu kişi, birinin sahibi, efendisi, lideri, başkanı, bir şeyi yöneten, idare eden, bir şeye hükmeden anlamlarına gelir (İsfehanî, 2011:325). Terim olarak; kadının kocası, eşi manasının yanı sıra; sözü dinlenilen, bir toplumda lider konumunda olan efendi ve büyükler ve Hz. Peygamber (s.a.v.)'in amcasının oğlu Hz. Ali (r.a) ve kızı Hz. Fatma (r.a)'dan doğan torunlarıyla onların soyundan gelenler için kullanılan bir unvan manalarına gelmektedir (İsfehanî, 2011:325).

Kelime Kur’ân-1 Kerîm'de “seyyid سيّّ" şeklinde eş, koca, efendi manasında bir ayette (Kur'ân, 12/25); "Sâda سادة" şeklinde sözü dinlenilen, toplumun lideri, önder olan anlamında da başka bir ayette bir defa olmak üzere toplam iki yerde geçmektedir (Kur'ân, 33/67).

Hadis-i Şeriflerde "seyyid" kavramı; kabile başkanı, topluluğun ileri gelen seçkin kimseleri, kölenin efendisi gibi anlamlarda kullanılmaktadır. Bu manadaki kullanımına örnek hadislere Rasûlüllah (s.a.v.), minberde bulunduğu bir sırada yanındaki Hasan (r.a)'ı işaret ederek; "Bu oğlum seyyiddir. Umulur ki Allah onun vasıtasıyla iki Müslüman firkanın barışmasın sağlar" (Buharî, Sulh,9) hadisi ve seyyid kavramının efendi, önder manasında kullanıldığı "Hasan ve Hüseyin cennet ehlinin gençlerinin iki seyyididirler" (Tirmizî, Menâsık, 31) hadisi ve "Biz, Abdulmuttalib'in çocukları cennet ehlinin seyyidleriyiz. Ben, Hamza, Ali, Cafer, Hasan, Hüseyin ve Mehdî" (İbn Mace, Fitan, 34) hadisi örnek verilebilir.

Ayrıca Hz. Muhammed (s.a.v.)'in ashabı, seyyid kelimesini aralarındaki faziletli kimseleri övmek için de kullanmışlardır. Hz. Ömer (r.a); "Ebu Bekir seyyidinizdir. "Seyyidiniz (Bilâl (r.a)'i azad etmiştir" (Buharî, Fedâilu'l-ashab, 23) diyerek seyyid kavramını faziletli manasında kullanmıştır. Bazı rivayetlerde de "seyyid" kavramının; aşiretin önderi, lideri, önde gelenleri (Ahmed b. Hanbel, 1/45) manalarında da kullanıldığı anlaşılmaktadır.

Görüldüğü gibi gerek Kur'ân'da ve gerek Hz. Peygamber (s.a.v.) ve gerekse ashab, "seyyid” kelimesini efendi, başkan, önder ve faziletli kimse manalarında kullanmışlardır.

\section{6. Ûlu'l-Emr}

Topluluk şeklide liderlik anlamına gelen kavramlardan başka biri de "Ulu'l-emr" kavramadır. Arapça'da "sahip" anlamina gelen "ulu اولو" kelimesi ile "iş-emir" anlamına gelen "emr أمر" kelimesinin yan yana gelmesiyle oluşmuş isim tamlaması şeklinde bir kavramdır. Sözlükte "iş sahibi, amir, idareci, yönetici, emir sahibi" (Enis, 1972: I,26) manalarına gelir. Emir kelimesi "iş" ve "buyurma" anlamlarını içerdiğinden "ulu'l-emr" hem yetkili hem de görevli kimseleri ifade etmektedir(Türcan, 2012: 295-297). Terim olarak; başta devlet başkanı olmak üzere toplumun üst yöneticilerini, toplumsal sorumluluk ve otorite sahibi kimseleri içine alan kapsamlı bir tabirdir (Türcan, 2012: 295-297).

Ulu'l-emr kavramı Kur'ân'da Nisa Suresi’nde iki yerde geçmektedir. Ayetlerin birincisi: “Ey İnananlar! Allah'a itaat edin, Peygambere ve sizden buyruk sahibi olanlara itaat edin. Eğer bir şeyde çekişirseniz, Allah'a ve ahiret gününe inanmışsanı onun halini Allah'a ve Peygambere bırakın. Bu, hayırlı ve netice

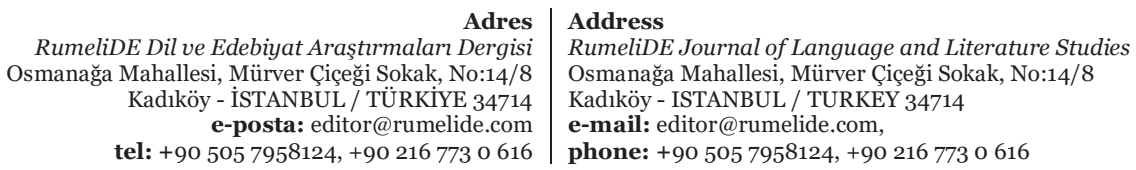


itibariyle en güzeldir" (Kur'ân, 4/59) Bu ayetin tefsirinde Ebu's-Suud, ulu'l-emr ile kastedilen kişiler, hak ve adalet üzere birleşen idarecilerdir. Bu idareciler de Hulefâ-i Râşidîn ve onların yolunda gidenlerdir demiştir (Ebu's-Suud, II, 180). Ulu'l-Emr kavramının geçtiği ikinci ayette ise Allah şöyle buyurmuştur:" Kendilerine güven veya korku hususunda bir haber geldiğinde onu yayarlar; hâlbuki o haberi Peygamber'e veya kendilerinden buyruk sahibi olanlara götürselerdi, onlardan sonuç çlkarmaya kadir olanlar onu bilirdi. Allah'n size bol nimeti ve rahmeti olmasaydl, pek azınız bir yana, şeytana uyardınzz" (Kur'ân, 4/83) Yine Ebu Suud'a göre burada ulu'l-emr kavramından da kastedilen din âlimleridir (Ebu's-Suud, II, 193). Bu ayetlerde ulu'l-emr kavramı için meallerde de; buyruk sahibi, idareci, yetkili, emir sahibi manaları verilmiştir.

Aynı terim çok fazla olmamakla birlikte hadislerde de kullanılmıştır. Ancak "ulu'l-emr" şeklinde değil de bazen "vulatu'l-emr," (Ahmed b. Hanbel, 7/183); bazan "vâli'l-emr," (Ahmed b. Hanbel, 1/429) bazen da "zu'l-emr" (İmam Malik, Cihad, 43) ifadeleriyle kullanılmıştır. Bunlar da hemen hemen "ulu'l-emr" ile aynı manada kullanılan ifadelerdir. Bu terimin hadislerde idareci ve komutan anlamında kullanıldığı, Kur'ân'daki kullanımına göre daha açık olarak görülmektedir.

Buraya kadar yapılan açıklamalardan da anlaşılacağı üzere ulu'l-emr kavramı emir verme yetkisini elinde bulunduran herkesi kapsayan genel bir terimdir. Ancak Kur'ân'da ulu'l-emre itaatin Allah'a ve peygambere itaatle birlikte zikredilmesi onların emirlerine uyulması gerekli olan kişiler olduklarına vurgu yapılmaktadır. Emir verme yetkisine sahip olan bu zümre kimlerdir? Ayetten anlaşllan o ki bu zümre Müslümanlardan olan ve Müslümanların yetki verdiği kimselerin tamamıdır denebilir. Ayrıca bu kimselerin, Allah'ın hükümlerini uyguladıkları müddetçe cins, renk, ırk bakımından hiçbir farklarının olmadığını şu hadisten rahatlıkla anlayabiliriz: "Ey Müslümanlar, Allah'tan korkun. Sizin başınıza amir olarak burnu ve kulağı kesik bir Habeşistanl köle bile getirilmiş olsa sizin için Allah’n kitabını tatbik ettiği müddetçe onun emirlerini dinleyin ve itaat edin" (Buharî, Ahkâm, 4).

Görüleceği üzere ulu'l-emr kavramı Kur'ân ve sünnetteki kullanımları itibariyle "yönetici, lider, önder, reis” şeklinde ortak manayı haizdirler. Ancak ulu'l-emr denilen kişilerin kimler olduğu Kur'ân'daki kullanımlarında açık ve net bir şekilde zikredilmezken, hadislerde yöneticilerin kastedildiği net bir şekilde açılklanmış, bu kimselere itaat etmenin zorunlu olduğuna vurgu yapılmıştır.

\subsection{Vezîr}

Çoğul anlamlı liderlik manası ifade eden bir başka kavram da "vüzera" kavramıdır. "Vezîr وزروز وزير "kavramı (وزر (V-Z-R kökünden türemiş çoğulu "vüzera olan tekil bir isimdir. Kelimenin sözlük anlamı; destek olmak, destek vermek, yardımcı olmak, (sırtındaki yükü) taşımak manalarına gelmektedir(Enis, 1972: I,1028). Terim olarak; halifenin görüşüne başvurduğu, güvendiği, memleket işleri için halifeye yardımcı olan kimse demektir (İbn. Manzur, VI, 4824).

Vezir kelimesi Kur'ân-ı Kerîm'de iki yerde geçmektedir. Geçtiği yerlerin ikisinde de konu Hz. Musa (a.s) ile kardeşi Hz. Harun (a.s) hakkındadır. Kur'ân'da Hz. Harun (a.s)'dan başka hiç kimse için "vezir" kelimesi kullanılmamıștır. Taha Suresi'ndeki ayette Hz. Musa (a.s): "Bir de bana ailemden bir vezir (yardımcı) ver" (Kur'ân, 20/29) demektedir. Ayette geçen vezîr kavramına Seyyid Kutup fi Zilali Kur'ân adlı tefsirinde şu izahı getirmektedir: "Hz. Musa (a.s), ailesinden bir yardımcr istiyor. Bu yardımcının da kardeşi Hz. Harun (a.s) olmasın belirtiyor. Çünkü kardeşi Hz. Harun (a.s) daha fasih konuşuyordu. Sinirleri sakin biri idi. Hz. Musa (a.s) ise çok heyecanl, keskin tabiath, çabuk kızan bir kişi idi. Bunun için kardeşini kendisine yardımcı olarak istiyordu" (Kutub, 2012: X,36) Vezîr

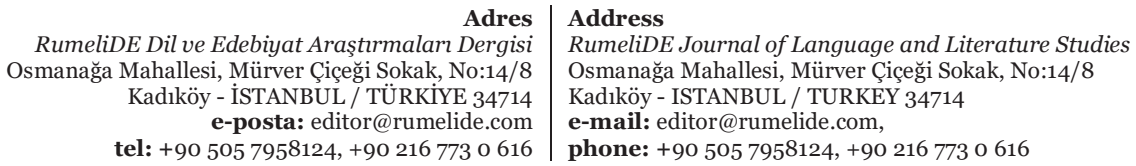


kavramının geçtiği diğer ayet de Furkan Suresidir. Orada Allah Hz. Musa (a.s)'ın isteğine cevaben "Andolsun ki Musa'ya kitap verdik, kardeşi Harun'u da ona vezir-yardımcı yaptık" (Kur'ân,25/35) buyururken vezir kelimesini kullanmıştır. Vezîr kavramının, geçtiği bu iki yerde de "yardımcı" manasında kullanıldığı açıkça görülmektedir.

Kur'ân'da zikredilen tüm peygamberler içinde "vezîr" kavramı sadece Hz. Musa (a.s) için kullanılmıştır. Bu da Hz. Musa (a.s)'ın kendi isteği üzerine ve kendinde bulunan bir eksiklikten dolayı gerçekleşmiştir. Dolayısıyla liderlikte asıl olan tek başlılıktır ancak liderdeki bir eksikliği gidermek üzere bir yardımcı tayini de mümkündür denilebilir. Liderlerin yanında onlara yardımcı olan bu sınıfa vezîrin çoğulu anlamında vüzerâ denmektedir.

Vezîr kavramının hadislerde de aynı manada kullanıldığına şahit olunmaktadır. Aşağıdaki hadis "vezîr" kavramının "yardımcı" manasında kullanıldığını açık bir şekilde göstermektedir. "Hz. Peygamber (a.s.) buyurdular ki: "Allah bir emir için hayır diledi mi ona doğru sözlü bir vezir nasip eder. Bu, ona unutunca hatırlatır, hatırladiğı zaman da yardım eder. Allah emire hayır dilemezse, kötü bir vezir musallat eder. Bu vezir, ona unuttuğunu hatırlatmaz, hattrlayınca da yardımcı olmaz" (Ebu Davud, Harac, 4)

\section{Sonuç ve tartışma}

Allah, insanı yaratıp bir takım bilgiler (isimler) öğrettikten sonra ona yeryüzünde halifelik görevini vermiştir. Aldığı bu görevle yeryüzü sahnesine çıkan ilk insan Hz. Adem (a.s)'dır. İnsanoğlu Adem (a.s)'dan sonra çoğalıp dünyaya dağılmış, topluluklar halinde yaşamaya başlamıştır.

Allah'ın halîfelik (liderlik, yöneticilik) görevi verdiği ilk insan Hz. Adem'den günümüze kadar kurulan tüm toplumlarda bir lidere sürekli ihtiyaç duyulmuştur. Dolayısıyla Kur'ân'a göre her insan sahip olduğu sosyal statüler gereği kendi çapında bir sorumluluğa sahiptir ve bundan dolayı da bir liderdir.

Kur'ân'da, insanın içinde yer aldığı sosyal yapılarda liderlik, yöneticilik görevini yürüten kimseleri ifade etmek için çok farklı kavramlar zikredilmektedir. Bu kavramların bazılarıyla devlet başkanları (halîfe, sultân, imam, melik gibi), devlet başkanlarının yardımcıları (mele', vezîr gibi), devletin bir kurumunun yöneticileri (nakîb, ekâbîr, sâdât gibi), toplumun en küçük yapı birimi olan aile gibi kurumların başında bulunan aile reisleri (râ’’’’ gibi), bazılarıyla da genel olarak toplumda herhangi bir sorumluluk taşıyan herkes (rầî, ulu'l-emr gibi) kastedilmiştir.

Liderlerde bulunması ve bulunmaması gereken nitelikleri, Kur'ân'da hikâyesi anlatılan peygamberler ve diğer liderlerden yola çıkılarak tespit etmek mümkündür. Kur'ân'a göre olumlu bir lider veya yöneticinin adaletli, bilgili, cesaretli, akıllı, cömert, yumuşak huylu, verdiği sözde duran, doğru sözlü, güvenilir, şefkatli, sabırlı, şükreden, affeden, öfkesine hâkim olan, istişareyi benimseyen, iffetli, güzel ve etkileyici konuşan, sır saklayan, yetenekli, Allah'tan korkan, başkalarının yerine kendini koyan, halkın ihtiyaçlarılla ilgilenen ve haksız kazanç kabilinden sayılabilecek hediyeleri kabul etmeyen biri olması gerekmektedir. Ayrıca lider veya yöneticilerin sahip olmamaları gereken bazı özellikler de zikredilmiştir. Bunlar; zulüm etmek, araştırıp-soruşturmadan akla aykırı hareket etmek, aceleci olmak, kibirli olmak, cahil olmak, müsrif ve cimri olmak, verdiği sözden dönmek ve yalan söylemek, öfkesine yenik düşmek, kibirli olmak, haset etmek, akrabayı kayırmak, sefih bir yaşam tarzına sahip olmaktır.

Liderlere verilen isimler, farklı dönem ve toplumlarda değişik adlar almıştır. Kuranda da liderler için farklı isimler kullanıldığı görülmektedir. Kur'ân'da münferit anlam ifade eden liderlikle ilgili kavramlar;

Adres $\mid$ Address

RumeliDE Dil ve Edebiyat Araşttrmaları Dergisi Osmanağa Mahallesi, Mürver Çiçeği Sokak, No:14/8 Kadıköy - İSTANBUL / TÜRKIYE 34714 tel: +90 $5057958124,+902167730616$

RumeliDE Journal of Language and Literature Studies

Osmanağa Mahallesi, Mürver Çiçeği Sokak, No:14/8

Kadıköy - ISTANBUL / TURKEY 34714

e-mail: editor@rumelide.com,

phone: +90 5057958124, +902167730616 
halîfe, imam, emîr, melik, sultân, ra'i lafizlarıyla isimlendirilirken sosyal bir sınıf olarak toplumu idare eden liderler sınıfı anlamı ifade eden liderler de sâdât, mütrefîn, vüzerâ, ûlu'l-emr, ekâbir, mele', nakîb gibi lafızlarla isimlendirilmişlerdir.

Ancak Kur'ân'da lider/ler anlamı ifade etmek için kullanılan isimler, olumlu-olumsuz bazı niteliklerle birlikte anılmıştır. Dolayısıyla lider anlamı ifade eden halîfe gibi bazı isimler, adaletli olmak ve bilgili olmak gibi evrensel niteliklerle birlikte anılırken mütrefîn gibi bazı isimler de toplumu yanlış yönlendiren, onlara iyi örnek olmamak, taşkınlık yapmak gibi niteliklerle birlikte anılmıştır. Ayrıca liderlik anlamı ifade eden halîfe gibi bazı isimler dünyayı bilgi ve adaletle yönetmek şeklinde zirvede bulunan lider manasında kullanılırken rầî gibi aile ve benzeri en küçük sosyal organizasyondan en büyük sosyal organizasyonu yönetmek şeklinde en genel manada sorumluluk üstlenme anlamını ifade etmek için kullanılmıştır.

Kur'ân'da geçen halîfe, emîr, sultân, melik gibi isimlerin İslâmiyet'in yayılmasıyla birlikte Müslüman devlet başkanları için kullanılırken; vüzerâ, nakîb gibi bazı isimler de Müslüman devlet başkanlarının danışmanı, yardımcısı anlamında kullanılmıştır.

\section{Kaynakça}

Ahmed b. Hanbel, Ebu Abdillah Ahmed b. Muhammed b. Hanbel b. Hilal eş-Şeybanî (1981). Müsned, Çağrı Yayınları, İstanbul.

Akyüz V. (1997). Kur'ân'da Siyasi Kavramlar, Kitabevi Yayınları, İstanbul.

Beyhâkî Ebû Bekir Ahmed b. Hüseyin (ts). Delâilü'n-Nübüvve ve Ma'rifeti Ahvali Sahibi'ş-Şeria, Daru'lKutubi'l-'ilmiyye, Beyrut.

Buharî Ebu Abdillah Muhammed b. İsmail b. İbrahim b. Mugire (1981). es-Sahih, Çağrı Yayınları, İstanbul.

Celaluddin Abdurrahman b. Ebi Bekr es-Suyûtî (ts.) Lübabu'n-Nukul fî̀ Esbâbi’n-Nuzûl, Çağrı Yayınınları, İstanbul.

Ebu Hayyan el-Endülüsî (1328h). Bahru'l-Muhît, Daru'l-Kutubu'l-i̇lmiyye, Kahire.

Ebu Dâvvud, Muhammed b. Süleyman b. İshak b. el-Ezdî es-Sicistânî (1981). es-Sünen, Çağrı Yayınları, İstanbul.

Ebu's-Suud Muhammed el-Amadî (ts.). İrşadu Akli’s-Selim ila Mezaya, Kur'âni'l-Kerim, Daru İhyai'tTurasi'l-Arabî, Beyrut.

ed-Dûrî Abdulaziz (1995). "Emîr" maddesi, DİA., XI, İstanbul.

Enis İbrahim., Muntasır A. (1972). el-Mu’cemu'l-Vasit, Mektebetu'l-İslâmiyye, İstanbul.

ez-Zebidî Muhibbuddin Ebi'l-Feyz es-Seyyid Muhammed Murtaza (1306h.). Tâcu'l-Arûs, Matbaatu'lHayriyye, Misir.

Firuzabadî Mecdüddin Muhammed b. Yakub (1993). el-Kamusu'l-Muhit, Müessesetu'r-Risale, Beyrut.

Gülgün U. (2006). "Nakîb” maddesi, DİA., XXXII, İstanbul.

Güner A. (2004), "Melik"maddesi, DİA, XXIX, 51-53.

İbn Cafer Muhammed b. Cerir et-Taberî (1388h). Câmiu'l-Beyân fî̀ Te’vîli'l-Kư'ân, (Thk., Mahmud Muhammed Şakir) Mektebetu İbnTeymiyye, Kahire.

İbn Hişam, Abdulmelik b. Eyyûb el-Himyerî (ts.). Siretu'n-Nebeviyye, Müessesetu 'Ulûmu'l-Kur'ân, Misir.

İbn Manzur Ebu'l-Fazl Muhammed b. Mukerrem (ts). Lisanu'l-Arabiye'l-Muhit, DaruLisani'l-Arab, Beyrut.

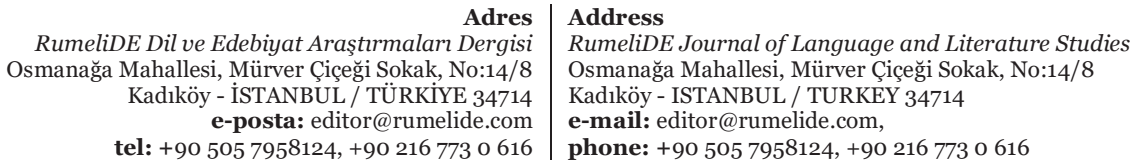


İbn Teymiyye Takiyyu'd-Dîn Ebu'l-Abbas Ahmed b. Abdi's-Selam b. Abdillah el-Harranî (1999). esSiyasetu'ş-Şer'iyye fî̀ İslahi'r-Râî ve'r-Râ’iyye ve'l-Hisbe fìll-İslâm, (Çev., Vecdi Akyüz), Dergah Yayınları, İstanbul.

İsfehanî, R. (1992). Mufradatu Elfazi'l-Kur’ân, (Thk., Davudî Safvan, Davudî) Daru'l-Kalem, Beyrut.

İsfehanî R. (ts). Mufradatu fi Garibu'l-Kuran, (Thk., Nizar Mustafa el-Bazir), MektebetüNizar Mustafa el-Bazir, Beyrut.

İslâmoğlu M. (2009). İmamlar ve Sultânlar, Düşün Yayıncılık, İstanbul.

Küçükaşcı M. S. (2004). "İmam”, DİA, XXII, İstanbul. 178-181.

Mâverdî, Ali b. Muhammed b. Ebi'l-Hasan Habib (2004) Kitabu'n-Nasihatu'l-Mulûk, Özgü Yay.,(çev., Mustafa Sarıbiylk), İstanbul.

Mâverdî, Ali b. Muhammed b. Ebi'l-Hasan Habib (2003). Devlet Yönetimi, İlke Yayınları (Çev., Mehmet Ali Kara), İstanbul.

Mâverdî, Ali b. Muhammed b. Ebi'l-Hasan Habib (1994) el-Ahkâmu's-Sultâniye, Bedir Yayınları (Çev., Ali Şafak), İstanbul .

Mâverdî, Ali b. Muhammed b. Ebi'l-Hasan Habib (1974). Nehcu's-Sulûk fî Siyâseti'l-Mulûk,(Çev., Mehmet Nahifi Efendi), İlke Yayıncllk, İstanbul.

Müslim Ebu'l-Hüseyin Müslim b. Haccac (1973) Sahih, (Çev., Ahmet Davutoğlu), Sönmez Yayınları, İstanbul.

Mutarrizî Ebu'l-Feth Nasiru'd-Dinu (1982). el-Muğrib, Matbaatu'n-Necme, Halep.

Nesâî Ebû Abdurrahman Ahmed b. Ali (1981). Sünen, Çağrı Yayınları, İstanbul.

Seyyid K. (ts.). Fi Zilali'l-Kur'ân, (Çev., M.Emin Saraç, İ. Hakkı Şengüller, Bekir Karlı̆̆a), Hikmet Yay., İstanbul.

Suyûtî Celaluddin Abdurrahman b. Ebi Bekr (ts). Lübabu'n-Nukul fî̀ Esbâbi'n-Nuzûl, Çağrı Yayınları, İstanbul.

Taberî Muhammed b. Cerîr (1967). Tarihu'l-Umemve'l-Mülûk,(Thk. Muhammed Ebu'l-Fadl İbrahim), I-XI, Beyrut.

Tirmizî Ebu İsa Muhammed b. İsa b. Seyre Musa b. Dehhak (1981). Sünen, Çağrı Yayınları, İstanbul.

Türcan, Talip (2012) "Ulu'l-Emr" maddesi, DİA, XXXXII, 295-297.

Özgüdenli Osman Gazi (2009). "Sultân” maddesi, DİA , XXXVII, İstanbul, 496-497.

Yücedoğru, Tevfik (2012). Mütref ve İnanç Esaslarına Etkisi, Uludağ Üniv. İlahiyat Fak. Dergisi, XXI, 1, 1-20.

Zemahşerî Muhammed b. Ömer (ts.). Tefsiru'l-Keşşaf 'an Hakaiki Ğavâmidi't-Tenzil ve Uyuni'l-Ekâvil, fi Vucûhi't-Te'vîl, (Thk., Fethi Abdurrahman; Ahmed Hicazî), Mektebetu'l-Abikan, Kahire. 